\title{
Online Learning during the COVID-19 Outbreak: Undergraduates' Perspective - A Case of the Faculty of Agriculture, University of Ruhuna, Sri Lanka
}

\section{S. U. Wagachchi, D. M. M. Sandeepani*, P. V. S. Harshana, G. C. Samaraweera}

${ }^{1}$ Department of Agricultural Economics, Faculty of Agriculture, University of Ruhuna, Sri Lanka

\section{Abstract}

In view of the ongoing COVID-19 pandemic, the mode of online learning has assumed an impactful role, especially in the field of higher education. The bulk of educational institutions have switched to online learning platforms for the continuation of academic programs. However, in the current literature on education, the perceptions of state university students on their engagements with this mode of learning have not yet been thoroughly examined. Therefore, this research was undertaken to investigate the perception of agricultural undergraduates towards online learning during the pandemic. The research examined the preferences of students for various characteristics of online classes, the

*Correspondence should be addressed to Ms. Shamindi Umayanga Wagachchi, Department of Agricultural Economics, Faculty of Agriculture, University of Ruhuna, Sri Lanka

Email: shamindiuw@gmail.com

https://orcid.org/0000-0001-6826-1221

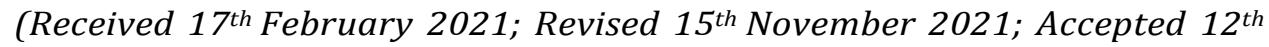
December 2021 (C) OUSL)

This article is published under the Creative Commons Attribution-Share Alike 4.0 International License (CC-BY-SA). This license permits use, distribution and reproduction in any medium; provided it is licensed under the same terms and the original work is properly cited. 
perceptions of online learning and the benefits and disadvantages encountered by students engaged in online learning during the pandemic through an online survey of 334 students. Independent samples t-test revealed that there is a significant difference ( $t$ (332) $=2.120, \mathrm{p}=0.035)$ in the choice of the duration of online classes between male $(M=3.55, S D=0.948)$ and female students $(M=3.81$, $\mathrm{SD}=0.913)$. Interestingly, results of the two-way ANOVA revealed that there is a statistically significant interaction between the effects of gender and academic year on students' interest in online learning, $F(3,326)=3.788, p=.011$. However, the majority of the students (41\%) faced connectivity/Network issues as their main problem during online learning. The homogeneity of the student group and the subject area limits the generalization of the findings to the vast majority.The study results can play a key role in developing future online classrooms with effective learning experiences.

Keywords: COVID-19, Online learning, Undergraduates

\section{Introduction}

\section{COVID-19 and the Sri Lankan Education Sector}

The deadly virus COVID-19 was first detected in Wuhan, South China in November 2019 and dispersed across the globe swiftly. The 22 million population of Sri Lanka had to deal with many consequences that were brought about by the Corona virus. The workforce from public and private sectors, self-employed people, large migrant workforce, country's daily wagers, school children as well as university students were forced to stay at home or at their respective staying places due to the lockdown restrictions imposed by the government. Although the schools and universities had to be shut down, the Sri Lankan government did not allow students to shut down their education. Accordingly, students were encouraged to engage in online learning strictly adhering to self-distancing, in order to continue the academic calendars. Most interestingly, a gazette was released on the subject by the Sri Lankan government. In line with this, all the Vice Chancellors were informed by the University Grant Commission (UGC) to switch and adjust to online platforms of education by giving free access to online services for all university students and faculty members.

However the universities and other education institutes faced a bigger crisis to cover-up the predefined syllabi in a stipulated time 
frame to go on par with their respective academic calendars. Moreover, more than 100,000 students are studying in the national universities in Sri Lanka according to the UGC, and there accessibility to digital devices like smartphones and other applications have not yet identified with official surveys. On the other hand, for the purposes of entertainment and communication, students often use technology. They lacked experience in studying, creating and developing information using technology (Suraweera, 2020). Therefore, the COVID-19 pandemic was a huge eye-opener for most of the stakeholders in the education sector to come up with creative digital solutions and adapt to online platforms like Zoom, Microsoft Teams, and Google Classroom etc. for the teachinglearning process in a short period of time after shelving traditional face-to-face lectures in institutional-based classrooms. This sudden shift of teaching (and learning) from a one mode of dissemination to another make it imperative to study the student perception of online learning in order to evaluate the system for better outcomes. Hence, this the online survey which was carried out to explore the perception and preferences of the undergraduates of Agriculture towards online learning and the attributes related to online classrooms. The study will be helpful in designing future online classes with a productive and effective learning environment.

This research study was conducted to achieve the following objectives:

1. To study the perception of university studentsduring the COVID19 pandemic towards different attributes of online learning.

2. To explore students' perception towards online learning during the COVID- 19 pandemic.

3. To examine the constraints faced by students while adopting online learning during COVID-19.

\section{Review of Literature}

\section{Different Approaches to Online Learning}

According to Bączek \& Wożakowska-Kapłon (2020), two different approaches were used in online education to deliver the contents of course module to university students. The primary mode used by educators is the self-directed learning approach, which allows the 
students to cope with their learning activities independently. Through instructor-led learning, educators facilitate the study resources and explanations through electronic learning.According to the University of Fordham website, there are three different types of online learning. One is asynchronous online learning where teaching and learning do not happen in real-time. The content and the tasks are provided earlier and students are given a time period to complete course work and exams. Teacher-student interaction typically takes place via message boards, blogs and wikis. Hence there is no meeting time for classes and students with time constraints or busy schedules would find asynchronous online learning advantageous. The second type is synchronous online learning. The teacher and all enrolled students are expected to communicate concurrently online with these types of platforms. Participants communicate through email, video or audio chat, similar in some respects to a webinar. Synchronous learning environments allow students in real-time to take part in a course from a distance. The third option is hybrid learning. Hybrid learning environments allow a blended mix including in-person and online interaction. Hybrid learning allows students and instructors to usually meet multiple times in person during a semester and provide computer-based contact between those face-to-face sessions.

\section{Benefits and Drawbacks of Online Learning}

Electronic learning is a feasible and cheap method that is used to improve the quality of university education during the pandemic situation. (Agarwal \& amp; Kaushik, 2020). A recent finding by Bączek et al., 2020 disclosed that online education increased the convenience of learning during the COVID-19 pandemic period as the students can easily access the learning resources at anytime and from anywhere. The flexible nature of online learning is emphasized by several other researchers as the main strength of online learning (Chizmar \& Walbert, 1999; Petrides, 2002; 2003; Kim et al. 2005). Moreover, the study materials can be delivered quickly and they can be easily standardized and updated. Introductions given through videos are more prominent in teaching practical skills rather than utilizing text-based resources. By engaging in electronic learning, students can be engaged in their learning continuously while improving their IT literacy. Additionally, online learning can cut the cost of accommodation due to the students' ability to learn at a convenient location. It also leads to the reduction of transport cost and the lack of carbon dioxide emission leads to low air pollution. 
Therefore the success of an online classroom depends on many significant factors such as using advanced technologies, well preparation of instructors, well-designed course structure (Sun and Chen, 2016).

The success of online education may heavily depend on the readily available and strong internet connection and proper IT skills. Availability of these requirements cannot be guaranteed from all the participants. Another critical issue of online learning is the cost of an effective internet connection. Even though some students have the ability to understand a given guidance via an online medium quickly and easily, some students need more instructions from their lecturers. Therefore, these students miss the direct explanations and communication within the conventional classroom which might reduce their learning opportunities. (Agung \& amp; Surtikanti, 2020). Online classes also have time limitations for learners who have troubles with self-discipline. Online education drives students to social isolation that will discourage their social competencies and learning skills. (Bączek et al., 2020)

\section{Online learning during the COVID-19 Pandemic in Sri Lankan}

During COVID-19 pandemic, LEARN's (Lanka Education and

Research Network) position as an internet service provider enabled the whitelisting of university web servers for access to online tertiary education. According to a report made by the Asian Development Bank (ADB Brief, 2020) 13 million activities (e.g., accessing reading materials, following lecture slides, taking online quizzes) were done by university students as well as lecturers by August 23, 2020.This approach benefited both students and lecturers greatly. This report further described that about 87 per cent of university students from the agriculture field had engaged in online learning during the COVID-19 pandemic. This is a positive sign in continuing online learning for agriculture students.

\section{Methodology}

\section{Participants}

The present study focused on the undergraduates' perception of online learning during the COVID-19 outbreak. Hence the undergraduates of the Faculty of Agriculture, The University of Ruhuna were selected as the respondents of the study where their academic curriculum ranges from social sciences to life sciences and 
their practical components range from lab to land. Furthermore, the participants were from three different degree programmes: BSc. Agriculture Resource Management and Technology, BSc. Agribusiness Management and BSc. Green Technology, and from four different academic years. Altogether 334 undergraduates participated in the research study.

\section{Procedure}

Initial the questionnaire was prepared with the help of a literature survey and pre-testing was done with five respondents and their feedback was considered in designing the final questionnaire. To assess the demographic features of the undergraduates the questionnaire was designed to assess preferences and perception of undergraduates towards online learning and digital devices and technical aids used in online learning. Furthermore, the advantages and drawbacks faced by the undergraduates during the pandemic when engaging in online learning were also assessed. The link for the Google form was sent to all the students of the faculty via their academic emails. The link was disabled after 14 days of circulation and 334 responses were obtained from three different degree programs and four different academic years at end of the process. Secondary data were collected from research paper articles, annual reports from the department of census and statistics, newspaper articles, UGC and other web sites etc.

\section{Data Analysis}

Data Analysis was done using the SPSS software. Descriptive statistics were used to analyze the students' perception of different attributes of online learning. A two-way ANOVA was conducted to examine the effect of gender and academic year on the perception of students for online learning. Descriptive statistics and independentsample t-test were used to analyze the students' perception of the benefits of online learning. Students' satisfaction towards online learning and the drawbacks they faced during online learning were assessed using descriptive statistics.

\section{Results and Discussion}

\section{Demographic Details of the Respondents}

Considering the majority of the sample comprised of females who were 80 percent, the males accounted for 20 percent of the sample. Taking the degree programme into account, 51 percent of the sample 
comprised of undergraduates of the BSc. Agriculture Resource Management and Technology degree programme. The BSc Agribusiness Management Degree programme accounted for 36 percent of the respondents whereas the lowest number of respondents were from BSc. Green Technology degree programme (13 percent). Majority of the respondents were from the first year and they represented 42 percent of the sample. The second-year students represented 24 percent of the sample whereas third-year students accounted for 19 percent. The lowest respondents were from the final year and represented 15 percent of the total respondents. Average monthly income of the respondents' families was Rs. 41,060.

Table 1.

Demographic details of the respondents.

\begin{tabular}{|c|c|c|}
\hline Variable & Categories & Percentage (\%) \\
\hline \multirow[t]{2}{*}{ Sex } & Male & 20 \\
\hline & Female & 80 \\
\hline \multirow[t]{3}{*}{ Degree } & $\begin{array}{l}\text { BSc. Agriculture } \\
\text { Resource } \\
\text { Management and } \\
\text { Technology } \\
\text { (AT) }\end{array}$ & 51 \\
\hline & $\begin{array}{c}\text { BSc Agribusiness } \\
\text { Management } \\
(\mathrm{AB})\end{array}$ & 36 \\
\hline & $\begin{array}{c}\text { BSc. Green } \\
\text { Technology } \\
\text { (GT) }\end{array}$ & 13 \\
\hline \multirow[t]{4}{*}{ Academic Year } & $1^{\text {st }}$ Year & 42 \\
\hline & $2^{\text {nd }}$ Year & 24 \\
\hline & $3^{\text {rd }}$ Year & 19 \\
\hline & Final Year & 15 \\
\hline
\end{tabular}

\section{Objective 1}

To understand the perceptions of university students towards different attributes of online learning during the COVID19 pandemic. 


\section{Attendance in Online Classes during the Pandemic}

98 percent of the respondents have attended online classes during the outbreak and only 2 percent of the sample did not attend classes (Figure 1). Those who attended allocated an average of 16.7 hours per week on online learning. Lack of internet facilities in the village/area and lack of a suitable mindset for a continuous learning engagement via the online mode were the main reasons that were highlighted by the students for not attending online classes during the pandemic.

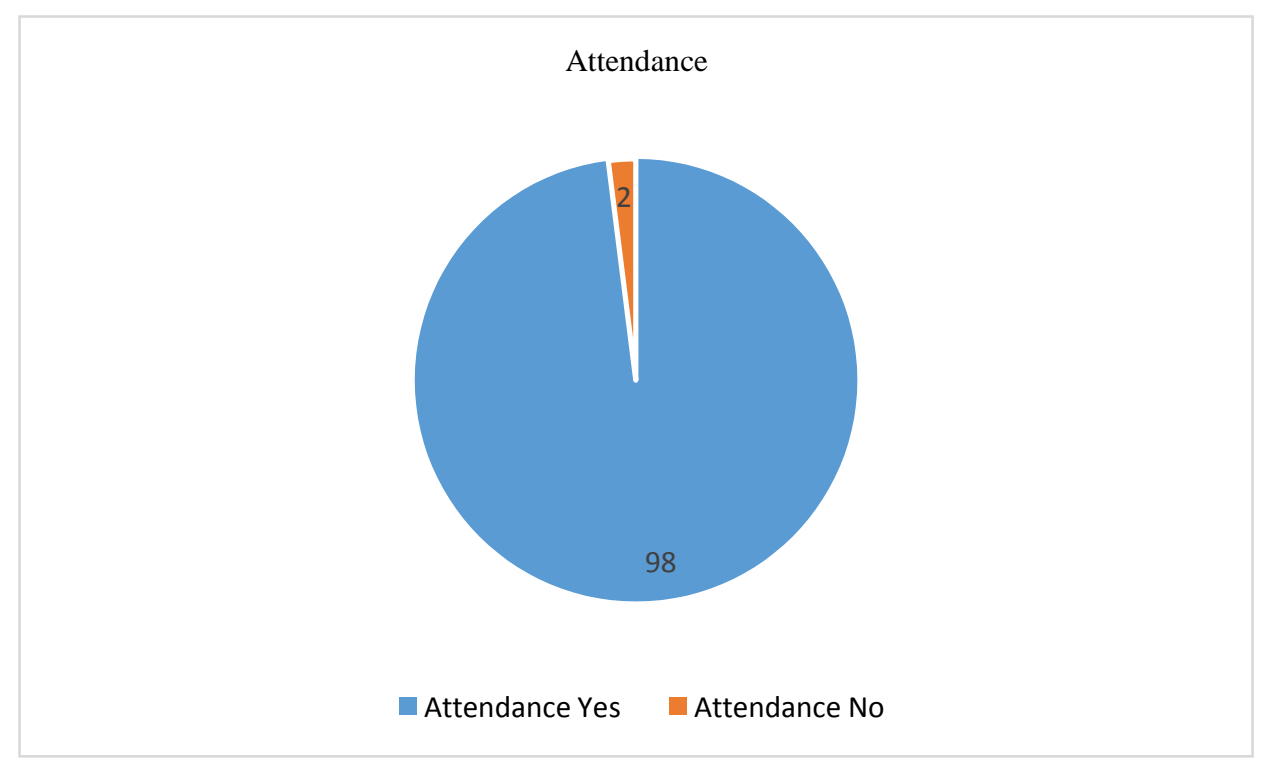

Figure 1. Attendance in online classes during the pandemic

\section{Technical Facilities used for Online Learning}

Majority of the respondents used mobile data as their main source of internet and it accounted for 63.8 percent of the sample. 20.4 percent of the respondents used both Wi-Fi and mobile data for their internet sourcing purposes. However, only 12.3 percent of the respondents have used their own Wi-Fi facility to browse the internet. Majority of the students accounting for 56 percent of the respondents ranked the laptop as their first choice of the devices used in online learning. However, our analysis proved that though the laptop was their first choice the majority of the respondents have actually used their mobile phones to engage in online learning accounting for 74 percent of the sample. 31.7 percent of respondents' ranked mobile phone as their first choice to engage in online learning. According to our results, although the laptop was ranked by the majority as their first choice, only 23.3 percent of the 
respondents have actually used it as their device to engage in online learning. This may be due to the problem of financial resources to purchase/hire IT devices. 2.1 percent of the respondents used tablets and only 0.6 percent of the respondents used domestic computers to engage in online learning (Table 2).

Table 2.

Technical facilities used for online learning.

\begin{tabular}{|c|c|c|}
\hline Variable & Categories & Percentage $(\%)$ \\
\hline \multirow[t]{5}{*}{ Source of internet } & Mobile data & 63.8 \\
\hline & Wi-Fi & 12.3 \\
\hline & $\begin{array}{c}\text { Wi-Fi and Mobile } \\
\text { data }\end{array}$ & 20.4 \\
\hline & $\begin{array}{l}\text { Free internet } \\
\text { sources from } \\
\text { government }\end{array}$ & 3.3 \\
\hline & Other & 0.3 \\
\hline \multirow[t]{5}{*}{ Device (Preference) } & Laptop & 56.3 \\
\hline & Mobile phone & 31.7 \\
\hline & Desktop & 1.8 \\
\hline & Tablet & 4.8 \\
\hline & Other & 0.6 \\
\hline \multirow{4}{*}{$\begin{array}{l}\text { Device (Actually } \\
\text { used) }\end{array}$} & Mobile phone & 74 \\
\hline & Laptop & 23.3 \\
\hline & Desktop & 0.6 \\
\hline & Tablet & 2.1 \\
\hline
\end{tabular}

\section{Structure and Learning Materials of Online Classes}

Table 3 depicts the structure and learning materials of online classes. Online classes with only theory lessons were ranked as the first choice of class type by the majority of the students accounting for 62.6 percent of the sample. Only 26.6 percent ranked online classes with both theory and practical lessons as their first choice of class type.

The majority of the respondents preferred having live online classes that can be recorded, which accounted for 51.8 percent of the 
sample whereas another 22.8 percent selected only live classes. 20.7 percent of the respondents wanted, recorded classes to be uploaded to the (Learning Management System) LMS without having live classes.

Regarding the nature of the course material majority of the respondents accounting for 78.4 percent of the respondents wanted video content with reading materials to be uploaded to the LMS. 15 percent of the respondents wanted only reading material to be uploaded to the LMS.

Considering the nature of the video content of online classes, 77.5 percent of the respondents wanted both PowerPoint presentation and whiteboard as their video content of online learning. However only 21.3 percent of respondents wanted only PowerPoint presentation and the lowest number of respondents wanted (0.3 percent) only the whiteboard.

Table 3. Structure and Learning Materials of Online Classes.

\begin{tabular}{ccc}
\hline Variable & Categories & Percentage (\%) \\
\hline Online class type & Only theory lessons & 62.6 \\
\cline { 2 - 3 } & $\begin{array}{c}\text { Both theory and } \\
\text { practical lessons }\end{array}$ & 26.6 \\
\cline { 2 - 3 } & $\begin{array}{c}\text { Giving quiz and } \\
\text { assignments without } \\
\text { conducting online } \\
\text { classes }\end{array}$ & \\
\cline { 2 - 3 } & $\begin{array}{c}\text { Only practical } \\
\text { lessons }\end{array}$ & 0.9 \\
\cline { 2 - 3 } Online class format & $\begin{array}{c}\text { Other } \\
\text { Live classes that can } \\
\text { be recorded }\end{array}$ & 0.6 \\
\hline
\end{tabular}




\begin{tabular}{|c|c|c|}
\hline & Live classes only & 22.8 \\
\hline & $\begin{array}{l}\text { Recorded classes to } \\
\text { be uploaded to the } \\
\text { LMS without having } \\
\text { live classes. }\end{array}$ & 20.7 \\
\hline & $\begin{array}{c}\text { Reading materials to } \\
\text { be sent to without } \\
\text { conducting online } \\
\text { classes. }\end{array}$ & 3.9 \\
\hline & Other & 0.9 \\
\hline \multirow[t]{5}{*}{$\begin{array}{l}\text { Nature of the } \\
\text { course material }\end{array}$} & $\begin{array}{l}\text { Video content with } \\
\text { reading materials to } \\
\text { be uploaded to the } \\
\text { LMS }\end{array}$ & 78.4 \\
\hline & $\begin{array}{l}\text { Only reading } \\
\text { material to be } \\
\text { uploaded to the LMS }\end{array}$ & 15 \\
\hline & $\begin{array}{l}\text { Only video content to } \\
\text { be uploaded to the } \\
\text { LMS }\end{array}$ & 2.4 \\
\hline & $\begin{array}{c}\text { Only video content to } \\
\text { be uploaded to the } \\
\text { YouTube }\end{array}$ & 2.7 \\
\hline & Any other & 1.5 \\
\hline \multirow[t]{4}{*}{$\begin{array}{l}\text { Nature of the video } \\
\text { content of online } \\
\text { classes }\end{array}$} & $\begin{array}{l}\text { Both PowerPoint } \\
\text { presentation and } \\
\text { whiteboard }\end{array}$ & 77.5 \\
\hline & $\begin{array}{c}\text { Only PowerPoint } \\
\text { presentation }\end{array}$ & 21.3 \\
\hline & Only whiteboard. & 0.3 \\
\hline & Any other & 0.9 \\
\hline
\end{tabular}

\section{Frequency and Time Attributes of Conducting Online Classes}

Table 4 summarizes the results of thefrequency and time attributes of conducting online classes. According to the results revealed by the study majority of the respondents, accounting for 41 percent of the sample, preferred having online classes as per the schedule to 
complete the semester. 25.7 percent chose alternate days as their most preferred frequency to conduct online classes.

Considering the time of conducting online classes different attributes were assessed in this study. The majority of the respondents, accounting to 87.4 percent of the sample, wanted their online classes to be held on weekdays whereas only 12.6 percent of the respondents wanted the classes held on the weekend.

Late morning was the most preferred time of the day (49.4 percent) to conduct online classes as selected by a majority of the respondents. 37.1 percent, 6.9 percent and 4.5 percent, of the respondents, have chosen early morning, evening and night respectively as their most preferred time of the day to conduct online classes. The lowest number of respondents ( 2.1 percent) have chosen the afternoon as their favorite time of the day to conduct online classes.

Most preferred time slot to conduct online classes for both theory sessions and practical session was 8-10 am as selected by the majority of the respondents accounting for 54.5 percent and 47.3 percent of the respondents respectively.

1.5 hours was selected as the best duration for an online class by the majority of the respondents (38 percent).However independent samples t-test revealed that there is a significant difference ( $t$ (332) $=2.120, \mathrm{p}=0.035)$ in the choice of the duration of online classes between male $(M=3.55, S D=0.948)$ and female students $(M=3.81$, $\mathrm{SD}=0.913)$. 31.7 percent of the respondents also selected 1 hour as their most preferred duration for an online class. A break of 15 minutes between online classes was preferred by the majority of respondents (29 percent).The majority (48.5\%) wanted to spend $2-4$ hours on online classes per day. 
Table 4.

Frequency and Time attributes of conducting online classes.

\begin{tabular}{|c|c|c|}
\hline Variable & Categories & Percentage \\
\hline \multirow[t]{6}{*}{ Frequency } & $\begin{array}{l}\text { As per the schedule } \\
\text { to complete the } \\
\text { semester. }\end{array}$ & 41 \\
\hline & Alternate days & 25.7 \\
\hline & Daily & 18.3 \\
\hline & Weekly twice & 8.4 \\
\hline & Weekly once & 5.1 \\
\hline & Any other & 1.5 \\
\hline \multirow[t]{2}{*}{ Time of the week } & Weekdays & 87.4 \\
\hline & Weekend & 12.6 \\
\hline \multirow[t]{5}{*}{ Time of the day } & Early morning & 37.1 \\
\hline & Late morning & 49.4 \\
\hline & Afternoon & 2.1 \\
\hline & Evening & 6.9 \\
\hline & Night & 4.5 \\
\hline \multirow[t]{6}{*}{ Time slot (Theory) } & $6 a m-8 a m$ & 26.3 \\
\hline & $8 a m-10 a m$ & 54.5 \\
\hline & $10 \mathrm{am}-12 \mathrm{pm}$ & 8.7 \\
\hline & $1 p m-3 p m$ & 1.2 \\
\hline & $3 p m-5 p m$ & 2.1 \\
\hline & $5 p m-7 p m$ & 3 \\
\hline
\end{tabular}




\begin{tabular}{|c|c|c|}
\hline & 7pm-9pm & 4.2 \\
\hline \multirow[t]{7}{*}{ Time slot (Practical) } & 6am-8am & 16.8 \\
\hline & $8 a m-10$ am & 47.3 \\
\hline & $10 a m-12$ pm & 19.2 \\
\hline & $1 p m-3 p m$ & 3.6 \\
\hline & $3 p m-5 p m$ & 6 \\
\hline & $5 p m-7 p m$ & 4.2 \\
\hline & 7pm-9pm & 3 \\
\hline \multirow[t]{6}{*}{ Duration } & $30 \mathrm{~min}$ & 1.2 \\
\hline & $45 \mathrm{~min}$ & 6 \\
\hline & 1 hour & 31.7 \\
\hline & 1.5 hours & 38 \\
\hline & 2 hours & 22.5 \\
\hline & More than 2 hours & 0.6 \\
\hline \multirow{5}{*}{$\begin{array}{l}\text { Break between two online } \\
\text { classes }\end{array}$} & $15 \mathrm{~min}$ & 29 \\
\hline & $30 \mathrm{~min}$ & 26.3 \\
\hline & $45 \mathrm{~min}$ & 4.8 \\
\hline & 1 hour & 26.6 \\
\hline & 1.5 hours & 13.2 \\
\hline \multirow{5}{*}{$\begin{array}{l}\text { Time spent on online classes } \\
\text { per day }\end{array}$} & Less than 1 hour & 2.1 \\
\hline & 1-2 hours & 21.6 \\
\hline & 2-4 hours & 48.5 \\
\hline & 4-6 hours & 24.9 \\
\hline & $6-8$ hours & 3 \\
\hline
\end{tabular}

\section{Objective 2}

Perception of Students towards Online Learning during the COVID-19 Pandemic

Respondents' perceptions were assessed using a five-point Likert scale. The analysis revealed that the 34.1 percent of the students were neutral about their love and interest in online learning and that they participated in it because they had no other options to cover lessons (31.7 percent). Interestingly, 36.2 percent of respondents stated that online learning provides great enthusiasm for them to learn. However, 34.1 percent of the students liked to learn new technology and they highly recommend online teaching and learning 
to other students disagreeing with the fact that online learning is a boring event. Furthermore, 34.1 percent of the respondents disagreed that online teaching and learning discouraged their interest in learning, implying that students are interested in learning with the online system.

A two-way ANOVA was conducted that examined the effect of gender and academic year on the perception of students for online learning. There was a statistically significant interaction between the effects of gender and academic year on the students' love and interest of online learning, $F(3,326)=3.788, p=.011$. Simple main effects analysis showed that females were significantly more interested in online learning than males in the 2 nd year $(p=.042)$ and third-year $(p=.015)$, but there were no differences between gender in the first year $(\mathrm{p}=.165)$ or the final year $(\mathrm{p}=.440)$. Furthermore, the analysis showed a statistically significant interaction between the effects of gender and academic year on students' preference for learning new technologies and recommending online learning for others, $F(3,326)$ $=4.793, \mathrm{p}=.003$. Simple main effects analysis showed that females were significantly more interested in online learning than males in 3rd year $(\mathrm{p}=.001)$, but there were no differences between the genders in the first year $(p=.580), 2$ nd year $(p=.140)$ or the final year $(\mathrm{p}=.440)$. There was a statistically significant interaction between the effects of gender and academic year on students perceptions on the ability of online learning to increase their enthusiasm to learn, $F(3,326)=3.074$, $p=.028$. However simple main effects analysis showed that there were no differences between gender in the first year $(p=.536), 2$ nd year $(p=.063)$, third year $(p=.093)$ or the final year $(p=.108)$ regarding the ability of online learning to increase the student's enthusiasm to learn. Furthermore, the analysis showed a statistically significant interaction between the effects of gender and academic year on students' perception that online learning could discourage their interest in learning, $F$ (3, $326)=3.832, \mathrm{p}=.010$. Simple main effects analysis showed that females were significantly more interested in online learning than males in the 2 nd year $(\mathrm{p}<.001)$, but there were no differences between the genders in the first year $(p=.946)$, third year $(p=.941)$ or the final year $(\mathrm{p}=.364)$. There was not a significant interaction between the effects of gender and academic year on students perception on attending online classes, because they had no other alternative during the pandemic, $F(3,326)=2.610, p=.052$. 
Moreover, there was a statistically significant interaction between the effects of gender and academic year on students' perception on the uninteresting nature of online classes and recommending/not recommending it to others. Simple main effects analysis showed that females were significantly more interested in the nature of online learning owing to its engaging nature and were most likely to recommend it to others than males in the 2 nd year $(p=.019)$, but there were no differences between gender in the first year $(p=.254)$, third year $(\mathrm{p}=.539)$ or the final year $(\mathrm{p}=.237)$.

\section{Table 5.}

Perceptions of students towards online learning during the COVID-19 pandemic

\begin{tabular}{lccccc}
\hline & $\begin{array}{c}\text { Strongly } \\
\text { disagree } \\
(\%)\end{array}$ & $\begin{array}{c}\text { Disagree } \\
(\%)\end{array}$ & $\begin{array}{c}\text { Neutral } \\
(\%)\end{array}$ & $\begin{array}{c}\text { Agree } \\
(\%)\end{array}$ & $\begin{array}{c}\text { Strongly } \\
\text { Agree } \\
(\%)\end{array}$ \\
\hline $\begin{array}{l}\text { 1. I participated } \\
\text { in online classes } \\
\text { with a great } \\
\text { interest as I love } \\
\text { online learning }\end{array}$ & 6 & 9 & 34.1 & 32.9 & 18 \\
\hline $\begin{array}{l}2 . \text { I like to learn } \\
\text { new technology } \\
\text { and I highly } \\
\text { recommend } \\
\text { online teaching } \\
\text { and learning }\end{array}$ & 5.4 & 8.1 & 30.8 & 34.1 & 21.6 \\
\hline $\begin{array}{l}3 . \text { Online } \\
\text { teaching and } \\
\text { learning give me } \\
\text { great } \\
\text { enthusiasm to } \\
\text { learn }\end{array}$ & & & & & \\
\hline
\end{tabular}




\begin{tabular}{|c|c|c|c|c|c|}
\hline $\begin{array}{l}\text { 4. Online } \\
\text { teaching and } \\
\text { learning } \\
\text { discourage my } \\
\text { interest of } \\
\text { learning }\end{array}$ & 24.3 & 34.1 & 26.6 & 11.7 & 3.3 \\
\hline $\begin{array}{l}\text { 5. I participated } \\
\text { in online classes } \\
\text { with low interest } \\
\text { as I have no any } \\
\text { other alternatives } \\
\text { to learn my } \\
\text { courses }\end{array}$ & 21.3 & 29.9 & 31.7 & 13.5 & 3.6 \\
\hline $\begin{array}{l}\text { 6. Online } \\
\text { learning is so } \\
\text { boring that I will } \\
\text { never recommend } \\
\text { it to anyone }\end{array}$ & 29.9 & 30.2 & 28.1 & 9.9 & 1.8 \\
\hline
\end{tabular}

Perceptions of Students towards the Benefits of Online Learning during the COVID-19 Pandemic

The study assessed the perception of students towards the benefits of online learning. 38.9 percent of the respondents stated that online learning gives a flexible schedule and convenience to them. 30.5 percent of the respondents stated online learning is more comfortable for them implying that students prefer online learning compared to traditional classrooms.43.1 percent of the respondents agreed that online learning helped them improve their technical skills implying students are more enthusiastic about learning new technology. Furthermore, 34.1 percent of the respondents agreed that online learning gave them greater ability to concentrate implying that students are more considerate about achieving selfdiscipline in their academic work. 30.8 percent of the respondents were neutral about the interactive nature of the online classes compared to traditional classes implying that students are not comfortable about the learning environment and steps need to be taken to enhance the interactive nature of online classes. 36.2 percent of the respondents stated that online learning enhanced their self-discipline and responsibility of learning indicating online learning has paved the path for students to be more responsible 
about their academic work. Furthermore, independent samples ttest revealed that there was a significant difference $(\mathrm{t}(332)=2.267$, $\mathrm{p}=0.024)$ in the perception of male $(\mathrm{M}=3.06, \mathrm{SD}=1.162)$ and female students $(\mathrm{M}=3.4, \mathrm{SD}=1.053)$ towards the ability of online learning to enhance their self-discipline and responsibility of learning.

\section{Table 6.}

Perceptions of students towards the benefits of online learning during the COVID-19 pandemic.

\begin{tabular}{|c|c|c|c|c|c|}
\hline & $\begin{array}{c}\text { Strongly } \\
\text { disagree } \\
(\%)\end{array}$ & $\begin{array}{c}\text { Disagree } \\
(\%)\end{array}$ & $\begin{array}{c}\text { Neutral } \\
(\%)\end{array}$ & $\begin{array}{c}\text { Agree } \\
(\%)\end{array}$ & $\begin{array}{c}\text { Strongly } \\
\text { Agree } \\
(\%)\end{array}$ \\
\hline $\begin{array}{l}\text { 1. Online } \\
\text { learning } \\
\text { gives a } \\
\text { flexible } \\
\text { schedule } \\
\text { and } \\
\text { convenienc } \\
\text { e }\end{array}$ & 3.9 & 7.8 & 26.9 & 38.9 & 22.5 \\
\hline $\begin{array}{l}\text { 2. Online } \\
\text { learning is } \\
\text { more } \\
\text { comfortable } \\
\text { for me }\end{array}$ & 5.1 & 9.3 & 30.5 & 30.5 & 24.6 \\
\hline $\begin{array}{l}\text { 3. Online } \\
\text { learning } \\
\text { helps to } \\
\text { improve my } \\
\text { technical } \\
\text { skills }\end{array}$ & 3 & 5.1 & 24.3 & 43.1 & 24.6 \\
\hline $\begin{array}{l}\text { 4. Online } \\
\text { learning } \\
\text { gives me } \\
\text { greater } \\
\text { ability to } \\
\text { concentrate }\end{array}$ & 4.8 & 11.7 & 32.9 & 34.1 & 16.5 \\
\hline
\end{tabular}




\begin{tabular}{|c|c|c|c|c|c|}
\hline $\begin{array}{l}\text { 5. I feel } \\
\text { online } \\
\text { learning is } \\
\text { more } \\
\text { interactive } \\
\text { than physical } \\
\text { classroom } \\
\text { lectures }\end{array}$ & 12 & 25.7 & 30.8 & 18.6 & 12.9 \\
\hline $\begin{array}{l}\text { 6. Online } \\
\text { learning } \\
\text { enhances my } \\
\text { self-discipline } \\
\text { and } \\
\text { responsibility } \\
\text { of learning }\end{array}$ & 7.2 & 11.7 & 36.2 & 30.8 & 14.1 \\
\hline
\end{tabular}

Satisfaction expressed of students towards online learning during the COVID-19 pandemic

The study assessed the satisfaction of respondents who faced the online classes conducted by the faculty during the pandemic. Overall, a majority of 45 percent and 50 percent of respondents have stated that they are satisfied with audio facilities and video content of the online classes respectively. Regarding the overall satisfaction about online classes majority of respondents (49 percent) have stated that they are satisfied with online classes that were conducted by the faculty. 45 percent of the respondents have recommended online classes for others and 87 percent of the respondents stated online learning should be made a part of the academic curriculum in the future.

\section{Objective 3}

Constraints that Affected Students when Adapting to Online Learning during COVID-19

The study assessed the constraints and limitations which affected the students in adapting to online learning during the pandemic (Table 7). Accordingly, majority of the students (40.7 percent) faced lack of connectivity/network issues as their main problem. Another 31.4 percent of the students faced data limitations and data speed issues. 8.4 percent of the sample stated that not having a personal internet connection is a barrier for them to engage in online learning. 


\section{Table 7.}

Constraints the students faced when adapting to online learning during COVID-19.

\begin{tabular}{lc}
\hline \multicolumn{1}{c}{ Barrier } & Percentage \\
\hline Lack of connectivity/network issues & 40.7 \\
\hline Poor digital skills & 2.7 \\
\hline Data limit and Data speed & 31.4 \\
\hline Lack of device & 3.9 \\
\hline Poor electricity & 5.7 \\
\hline No face to face interaction & 8.4 \\
\hline Any other (Please specify) & 7.2 \\
\hline
\end{tabular}

\section{Conclusion}

To keep up with the academic calendars, colleges, universities and institutions are switching to online channels.It could be too early to tell how online learning is perceived by students who are reorienting themselves to a newer mode of learning. However, understanding the preparation and perceptions of students is an important objective of this research. .The results of this analysis revealed that the majority of the students showed promising results in the wake of COVID-19 towards online learning. Most of the students were satisfied with online learning and they wanted to recommend it to others and make online learning a part of the academic curriculum in the future. The laptop was the first choice of device for the majority of students for online learning. The majority of the students wanted to arrange the online classes as per the schedule to complete the semester on weekdays during the late morning from 8:00 to 10:00 am, with duration of 1.5 hours. However the majority of the students faced lack of connectivity/network issues as their main problem during the pandemicTherefore these variables should be taken into consideration when developing an online course to make the teachinglearning process more successful. 


\section{References}

Agarwal, S. \& Kaushik, J. S. (2020). Student's Perception of Online Learning during COVID Pandemic. Indian Journal of Pediatrics, 87(7), 554.

DOI:https://doi.org/10.1007/s12098-020-03327-7

Agung, A. S. \& Surtikanti, M. W. (2020). Students' Perception of Online Learning during COVID-19 Pandemic: A Case Study on the English Students of STKIP Pamane Talino.SOSHUM. Jurnal Sosial Dan Humaniora, 10(2), 225-235.

DOI: http://dx.doi.org/10.31940/soshum.v10i2.1316

Bączek, M. Z.-B., \& Wożakowska-Kapłon, B. (2020). Students' perception of online learning during the COVID-19 pandemic: a survey study of Polish medical students. Research Square, 1-14. DOI:10.21203/rs.3.rs-41178/v1

Chizmar, J. F. (1999). Web-based learning environments guided by principles of good teaching practice. The Journal of Economic Education, 30(3), 248-259.

DOI: $10.1080 / 00220489909595985$

Hayashi, R. G. (2020). Online Learning in Sri Lanka's Higher Education Institutions. ADB BRIEFS.

Kim, K. J. (2005). Online MBA students' perceptions of online learning: Benefits, challenges, and suggestions. The Internet and Higher Education, 8(4), 335-344.

DOI:10.1016/J.IHEDUC.2005.09.005

Lim, D. H. (2007). Online vs blended learning: differences in instructional outcomes and learner satisfaction. Journal of Asynchronous Learning Networks, 11(2), 27-42.

McVay, M. (2000). Developing a web-based distance student orientation to enhance student success in an online bachelor's degree completion program. Ed.D. Program. Florida: Nova Southeastern University.

McVay, M. (2001). How to be a successful distance learning student: Learning on the Internet. New York: Prentice Hall.

Petrides, L. (2002). Web-based technologies for distributed (or distance) learning: Creating learning-centered educational 
experiences in the higher education classroom. International Journal of Instructional Media, 29(1), 69-77.

Smith, P. J. (2003). Towards identifying factors underlying readiness for online learning: an exploratory study. Distance Education, 24(1), 57-67.

DOI: $10.1080 / 01587910303043$

Sun, A. (2016). Online education and its effective practice: A research review. Journal of Information Technology Education, 15.

DOI: $10.28945 / 3502$

Suraweera, N. (2020). E-Learning for Continuing University Education. $30^{\text {th }}$ March 2020: Daily News E Paper.

(n.d.). Types of Online Learning . (2020). Fordham University: https://www.fordham.edu/info/24884/online_learning/7897/ types_of_online_learning

UGC. (2020). Online Teaching and Learning Activities of the State Universities under the UGC.2020.

https://cmb.ac.lk/online-teaching-learning-activities

Warner, D. C. (1998). Readiness of VET clients for flexible delivery including on-line learning. Brisbane: Australian National Training Authority. 